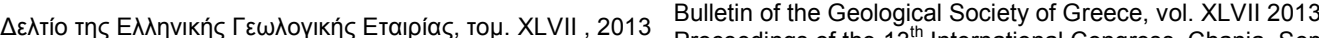
Proceedings of the $13^{\text {th }}$ International Congress, Chania, Sept.

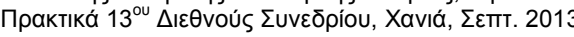
2013

\title{
ORIGIN OF THE HIGH-K TERTIARY MAGMATISM IN NORTHERN GREECE: IMPLICATIONS FOR MANTLE GEOCHEMISTRY AND GEOTECTONIC SETTING
}

\author{
Pipera K. ${ }^{1}$, Koroneos A. ${ }^{1}$, Soldatos T. ${ }^{1}$, Poli G. ${ }^{2}$ and Christofides G. ${ }^{1}$ \\ ${ }^{I}$ School of Geology, Aristotle University of Thessaloniki, 54124, Thessaloniki, Greece, \\ piperakyr@gmail.com,koroneos@geo.auth.gr,soldatos@geo.auth.gr,christof@geo.auth.gr \\ ${ }^{2}$ Department of Earth Sciences, University of Perugia, Piazza Università, 06100 Perugia, Italy, \\ polig@unipg.it
}

\begin{abstract}
Tertiary plutonic and volcanic rocks cropping out in the Rhodope Massif (N. Greece) are studied using existing and new geochemical and isotopic data. Most of these rocks belong to the post-collisional magmatism formed as part of the prolonged extensional tectonics of the Rhodope region in Late CretaceousPaleogene time. This magmatism is considered to be of mantle origin; however, the character of the mantle source is controversial. Rock bulk chemistry and compositional variations show magmas with calc-alkaline to high-K calc-alkaline and shoshonitic features associated with magmatism at convergent margins. Initial ${ }^{87} \mathrm{Sr}{ }^{86} \mathrm{Sr},{ }^{143} \mathrm{Nd} d^{144} \mathrm{Nd}$ ratios, $\mathrm{Pb}$ isotopes and REE composition of the mafic rocks indicate mainly an enriched mantle source, even if some rocks indicate a depleted mantle source. Low- and High-K mafic members of these rocks coexist indicating a strongly heterogeneous mantle source. The High-K character of some of the mafic rocks is primarily strongly related to mantle enrichment by subduction-related components, rather than crustal contamination. The geochemical characteristics of the studied rocks (e.g Ba/Th,Th/Yb,Ba/La, U/Th, Ce/Pb) indicate that primarily sediments and/or sediment melts, rather than fluid released by the subducted oceanic crust controlled the source enrichment under the Rhodope Massif.

Keywords: Rhodope Massif, Mantle geochemistry, Geotectonic Setting, K-rich Magmatism.
\end{abstract}

\section{Пері́ $\eta \psi \eta$}

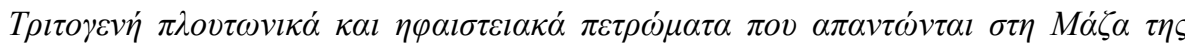

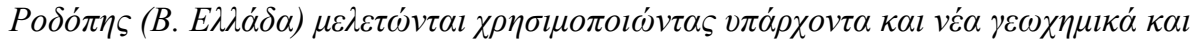

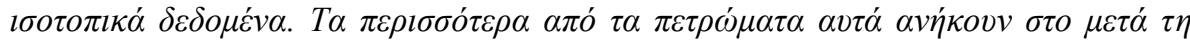

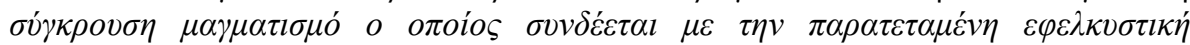

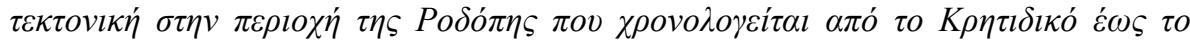

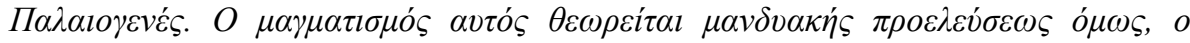

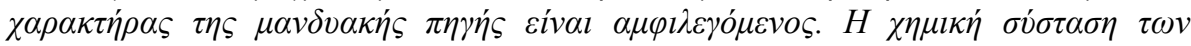

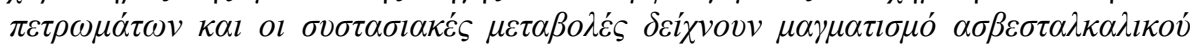

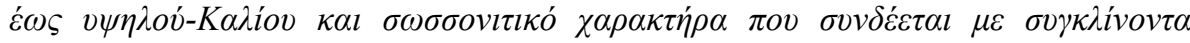




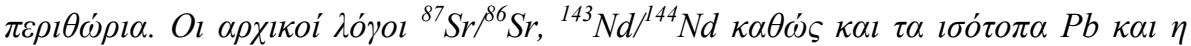

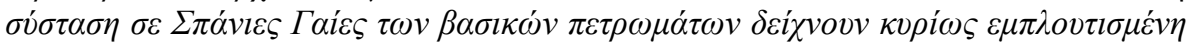
$\mu \alpha v \delta v \alpha \kappa \dot{\eta} \pi \eta \gamma \eta \dot{~ \alpha \nu ~ \kappa \alpha l ~ \kappa \alpha ́ \pi о l \alpha ~ \pi \varepsilon \tau \rho \omega ́ \mu \alpha \tau \alpha ~ \delta \varepsilon i ́ \chi v o v v ~ \varepsilon \kappa \pi \tau \omega \chi \varepsilon v \mu \varepsilon ́ v \eta . ~ Х \alpha \mu \eta \lambda о v ́-~ \kappa \alpha l ~}$

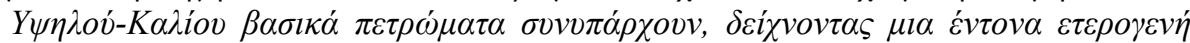

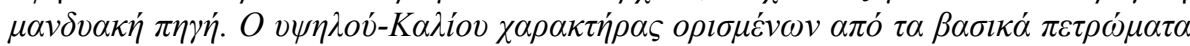

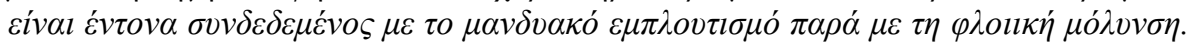

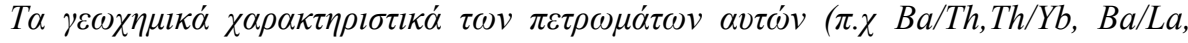

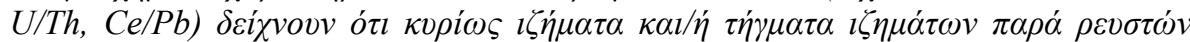

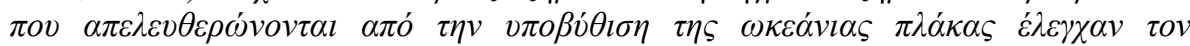

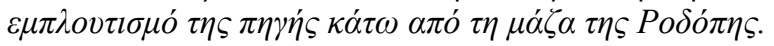

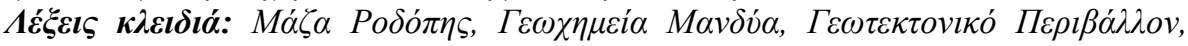

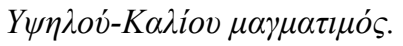

\title{
1. Introduction
}

The Rhodope Massif (N. Greece) is defined as a key area for understanding the evolution of the Tethyan systems. Due to the complexity of the area many researchers have focused on its tectonic and magmatic evolution separately and some efforts have been made to combine petrology and tectonics. Various Tertiary plutonic and volcanic rocks crop out in the Rhodope Massif with most important occurrences those of Vrontou, Xanthi, Elatia, Maronia, Leptokarya-Treis VrysesChalasmata, Evros, Samothraki and Dipotama-Kalotyho (Figure 1). Different hypotheses have been suggested on the nature of the source and the crustal contamination controlling their composition. A great deal of research has been made regarding their geochemistry and evolution as well as their origin, and many geochemical data have been published (Del Moro et al., 1988; Eleftheriadis et al., 1989; Mavroudchiev et al., 1992; Jones et al., 1992; Pe-Piper et al., 1998; Christofides et al., 1998, 2002, 2011; Soldatos et al., 1998, 2008; Papadopoulou et al., 2004; Vlahou et al., 2006). The Tertiary magmatism of Rhodopes is considered as the result of crustmantle interaction; however the nature of the mantle component is controversial. In order to address the nature of the mantle source, the role of crustal contamination and the process of their formation during the Tertiary tectonic events in Rhodope Massif the basic members of the magmatic rocks, which are considered crucial for the nature of their source, are studied. In detail, the trace element geochemistry and their isotopic characteristics are examined.

\section{Geological Setting}

\subsection{The Rhodope Massif}

The Rhodope Massif (RM) is a polymetamorphic terrain extending along the Greek-Bulgarian border and covers part of the north-eastern Macedonia and western Thrace in Greece and southeastern Bulgaria (Figure 1) as well as a small part of north-western Turkey. It is located in the frontal part of the Eurasian continental margin. It was assumed to have been formed from the closure of one subduction-exhumation cycle, the closure of the Paleo-Tethys ocean. It comprises mostly continental rocks with intercalations of oceanic material and represents the northernmost part of a southwest vergent Alpine nappe stack that developed during convergence between Africa and Europe from Jurassic to Neogene times (Papanikolaou and Panagopoulos, 1981; Burg et al., 1996; Ricou et al., 1998; Barr et al. 1999).

The northern border of the RM is defined by the west-northwestern-striking Maritsa fault in Bulgaria, which is composed of a series of subparallel, mainly dextral strike-slip faults (Burg et al. 1996, Georgiev et al., 2009). To the west the top-to-the-SW Tertiary Strymon detachment (Dinter and Royden, 1993; Sokoutis et al. 1993; Dinter et al. 1995; Lips et al. 2000) separates the RM from the Serbomacedonian Massif. To the east, the RM is structurally overlain by the Circum 
Rhodope Belt (Kaufmann et al., 1976; Kockel et al., 1977; Meinhold et al., 2010), comprising greenschist-facies rocks and ophiolites.

The subdivision of RM into different units is a subject of debates by many workers (e.g., Papanikolaou and Panagopoulos 1981; Mposkos 1989; Kilias and Mountrakis, 1990; Dinter et al., 1995; Burg et al. 1996; Krohe and Mposkos, 2002; Bonev et al., 2006; Georgiev et al., 2010; Turpaud, 2006; Bonev and Stampfli, 2008; Liati et al., 2011). Some schemes are based on structural criteria (e.g. Burg et al., 1996) other on metamorphic facies distinction (e.g. Krohe and Mposkos, 2002) and lately on geochronological data (Turpaud, 2006; Turpaud and Reischmann, 2010). A commonly used division for the Greek part of RM (central and western), based both on geological and petrological criteria, is the one proposed by Papanikolaou and Panagopoulos (1981), with an upper tectonic unit (UTU, also known as Sidironero unit) and a lower tectonic unit (LTU, also known as Pangaeo unit), separated by a SSE-NNW striking, northeast-dipping, thrust fault zone (Nestos thrust).

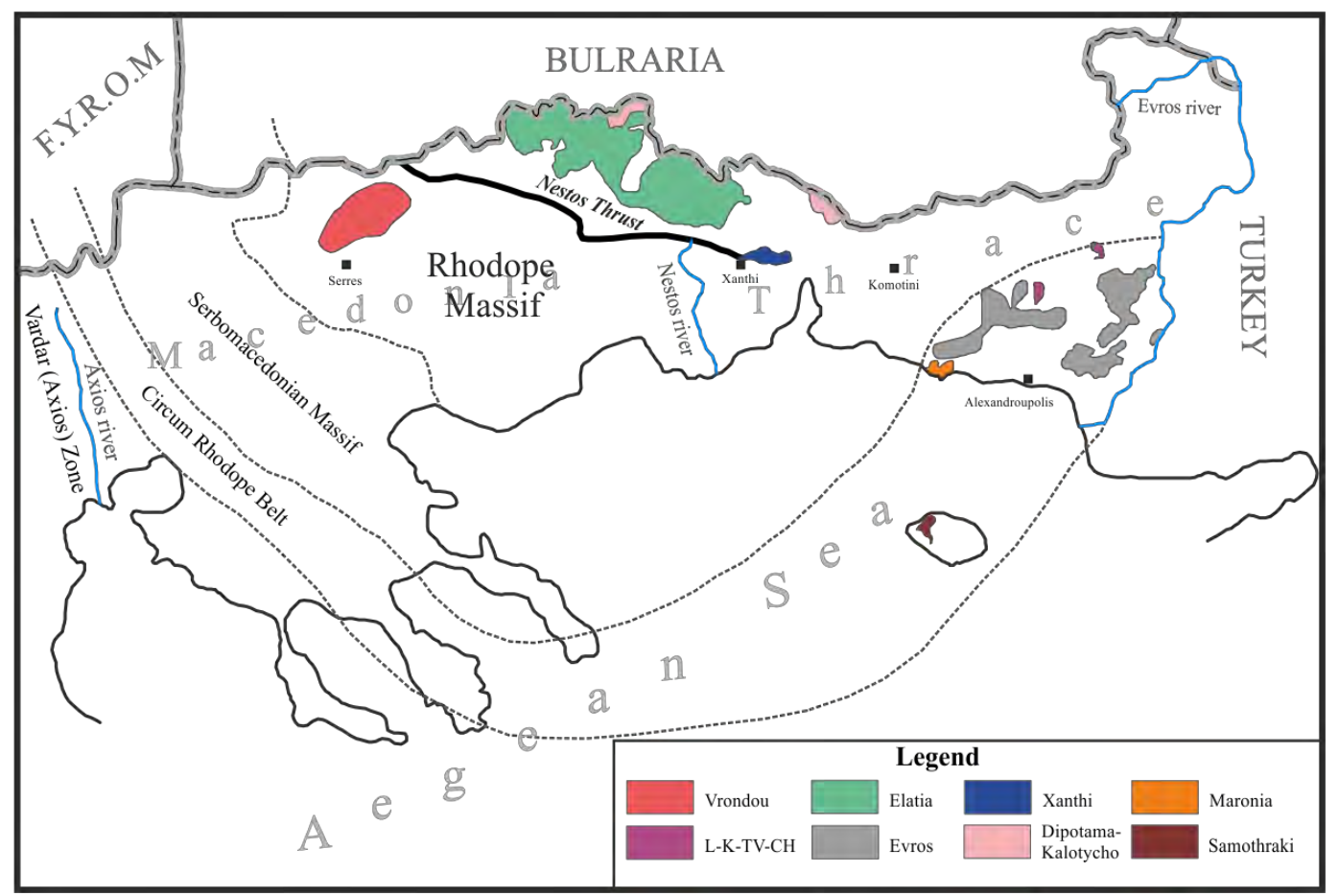

Figure 1 - Schematic map of Northern Greece with the locations of the studied rocks.

\subsection{Tertiary Magmatic Activity}

The extensional deformation of RM resulted in strong crustal thinning which started in Eocene (Kilias et al, 1999; Burchfiel et al., 2003; Brun and Sokutis, 2007) or earlier in Early Paleocene (Bonev et al, 2006). A strong crustal thinning in back-arc areas is usually associated with magmatism. Post - collisional magmatism of Paleogene to Neogene age (plutonic and volcanic, Figure 1) variable in composition, space, and time dominates the RM (Koukouvelas \& Pe-Piper, 1991; Dinter et al., 1995; Burg et al., 1996; Kilias \& Mountrakis, 1998; Christophides et al., 2001, 2004; Marchev et al., 2005; Bonev et al., 2006). Similar magmatic activity exists also in the continuation of RM in north-western Turkey (Bonev et al., 2007 and references therein). This magmatism is associated probably with the subduction of Pindos ocean; however, the remnant of the subducted slab of the Eastern margin of the opened, until the Tertiary time, Vardar-Axios ocean could also be the driving mechanism for the Tertiary magmatic activity in the Rhodope province or Vardar oceanic lithospheres (see Perugini et al., 2004; Kilias et al., 2011).

XLVII, No $1-418$ 
The presence of fault-controlled extensional basins with intrusive and extrusive magmatism dominated the RM. Volcanic rocks are found north of Xanthi in the Dipotama-Kalotycho are, in western Thrace in the extensive area of Alexandroupolis the Evros volcanic rocks (EVR) and in the island of Samothraki (Figure 1). The Dipotama-Kalotycho Oligocene volcanic rocks cut across the crystalline basement of the RM and are structurally associated with the formation of sedimentary (extensional) basins and consist mainly of intermediate to basic rocks apart from the Dipotama area where only felsic rocks occur (Eleftheriadis, 1995). The EVR are in close association with fault-controlled sedimentary basins. Three volcanic areas, namely Loutros-FeresDadia, Kirki-Esimi and Mesti-Petrota, after the corresponding basins, are distinguished. Their composition ranges from basaltic andesite to rhyolite through andesite, trachyandesite, trachydacite and dacite (Christofides et al, 2002). It is to note that, since so far isotopic data are not available for the EVR, these rocks are not included in the present study. The Samothraki volcanic rocks are overlying an Eocene clastic neritic sequence. They are distinguished in three main groups based on their field occurrence and geochronology: the "old" group comprising basalts to latites, the "intermediate" group of andesites to latites and the "young" group of latites and rhyolites (Vlahou et al., 2006).

Many plutonic rocks of post-collisional origin are also found in the RM, apart from the Elatia pluton that is considered to be of subduction tectonic environment (Soldatos et al., 2008). It constitutes the main part of the Elatia-Skaloti-Paranesti granitic complex. Its main lithology is a (hornblende)-biotite granodiorite with a marginal porphyritic phase. The eastern part of the pluton is occupied by a two-mica granite which intrudes the granodiorite. The Maronia pluton northwards and westwards intrudes marbles of the metasedimentary series of the Makri unit causing a rather wide zone of contact metamorphism (skarn) (Doryphoros, 1990). Eastwards it intrudes a metamorphic sequence of phyllites, greenschists and gneisses of the overlying metavolcanosedimentary series of the same unit causing intense thermal metamorphism to the surrounding rocks (hornfelses), while southwards the pluton itself is intruded by a small body of porphyritic micro-granite. Three main rock types have been distinguished: a) the basic group, with gabbros b) the intermediate group, with monzogranite to quartz-monzogranite and c) the felsic group, with granite in the form of dykes (Papadopoulou et al., 2004). The Xanthi pluton is in magmatic contact with Pangaion marbles to the west and gneisses and marbles of Sidironeron Unit. There is a contact metamorphic aureole typically a few hundred meters wide (Christofides, 1977; Liati, 1986). To the east the pluton cuts Eocene-Oligocene sedimentary rocks (dominantly flysch) which are intruded by andesitic dykes.

\section{Analytical Methods}

Some major elements used in the present study were taken from previous authors (Eleftheriadis, 1995; Christofides et al, 2002; Papadopoulou et al., 2004; Vlahou et al., 2006; Soldatos et al., 2008; Christofides et al. 2011) as well as the isotopic composition of $\mathrm{Sr}$ and $\mathrm{Nd}$ apart from the Xanthi and Vrontou plutons. The rest of the samples were analysed for major elements by X-ray fluorescence (XRF) in Saint Mary's Univeristy, Halifax, Nova Scotia, Canada, and the Acme Analytical Laboratories (Vancouver) Ltd, Canada. All trace elements and REE analyses were performed on a laser ablation quadrupole inductively coupled plasma mass spectrometry (LA ICPMS) in the Department of Earth Sciences, University of Perugia, Italy and on an quadrupole inductively coupled plasma mass spectrometry (ICP-MS) in the Acme Analytical Laboratories (Vancouver) Ltd, Canada. Additional analyses of some transitional elements already analyzed by ICP-MS, were determined by X-ray fluorescence (XRF) at Saint Mary's Univeristy, Halifax, Nova Scotia, Canada. The isotopic Sr and Nd content from Xanthi and Vrontou samples were determined in the Department of Lithospheric Research, University of Vienna, Austria. 


\section{Geochemical Characteristics}

\subsection{Major Elements}

Most samples both plutonic (Figure 2a) and volcanic (Figure 2b) belong to the calk-alkaline, high$\mathrm{K}$ and shoshonitic series. All rocks demonstrate a wide range on $\mathrm{SiO}_{2}$ content. The Elatia pluton consists mainly from felsic rocks and so far was considered to be of crustal origin. During the present work several mafic microgranular enclaves of basic composition were found on the northern part and analysed. This redefines the aspect of a crustal origin for the Elatia pluton and in the present paper is considered as a mantle derived rock.

\subsection{Trace Elements}

Geochemical characteristics for representative mafic rocks are illustrated for each area in primitive mantle normalized multi-element diagrams (Figure 3). Most of the rocks, show similar patterns with LILE enricjment and HFSE depletion. Few basic rocks indicate LILE depletion which is not accompanied by HFSE enrichment. One sample from Samothraki and one from Vrondou show relative $\mathrm{Nb}$ and Ta enrichment. In Figure 4 trace elements diagrams are used as indicators of fluid or sediment component enrichment ( $a$ and $b$ ) of the mantle wedge and the degree of the source enrichment (c).

\subsection{Rare Earth Elements (REE)}

The REE chondrite normalized patterns of the rocks are illustrated in the Figure 5. All rocks are enriched in LREE and slightly depleted in HREE. One sample of Samothraki exhibits parallel to Chondrite pattern showing a strongly depleted mantle source. Most samples exhibit negative Eu anomaly and some samples no $\mathrm{Eu}$ anomaly. Eu anomaly can be produced by plagioclase fractionation, residual plagioclase in the source or source contamination by slab-derived fluids and sediments (Ellam \& Hawkesworth, 1988). Since most samples have high Al content it means that they have not undergone significant plagioclase fractionation but contamination from the Rhodope metamorphic lithologies or source contamination from the subducted crust.

\subsection{Isotopic Data}

In Figure 6 the ${ }^{143} \mathrm{Nd} /{ }^{144} \mathrm{Nd} \mathrm{vs}{ }^{87} \mathrm{Sr} /{ }^{86} \mathrm{Sr}$ available data are illustrated. There is a wide range on both $\mathrm{Nd}$ and $\mathrm{Sr}$ isotopes for each area which implies the different degrees of contamination. Most samples are plotted between EM-I (Enriched Mantle I) and EM-II (Enriched Mantle II) mantle reservoirs supporting the enriched mantle source of these rocks. There are samples that demonstrate a more depleted component both for $\mathrm{Nd}$ and $\mathrm{Sr}$ isotopes especially samples from Xanthi, Samothraki and Elatia and the trend of most samples is towards DMM reservoir rather than continental crust.

\section{Discussion and Conclusions}

The Rhodope magmatic rocks are undoubtedly of orogenic origin as already stated by many previous workers (see 2.2). A subduction mechanism proposed for the Tertiary magmatism of Rhodope which persisted for many million years. Due to the variations on the Rhodope magmatism many more complicated subduction models have been proposed (see Marchev et al., 2004). Morover asthenospheric contribution is confirmed in the Bulgarian part of Rhodope. Rollback and slab break off is one of them and was suggested for the magmatism in the Aegean region. It leads to the heating of the lithospheric mantle by upwelling of the asthenosphere and melting of its enriched layers. Different degrees of partial melting produce magmas ranging from alkaline to ultrapotassic, whereas slightly higher degrees of melting produce calk-alkaline melts. Another model is delamination of the thickened crust after the continental collision proposed by 
Yanef et al. (1998). It differs from the slab break off model cause it predicts rapid intrusion of the asthenosphere in the place of the delaminated mantle and eclogitized lower crust resulting in uplift
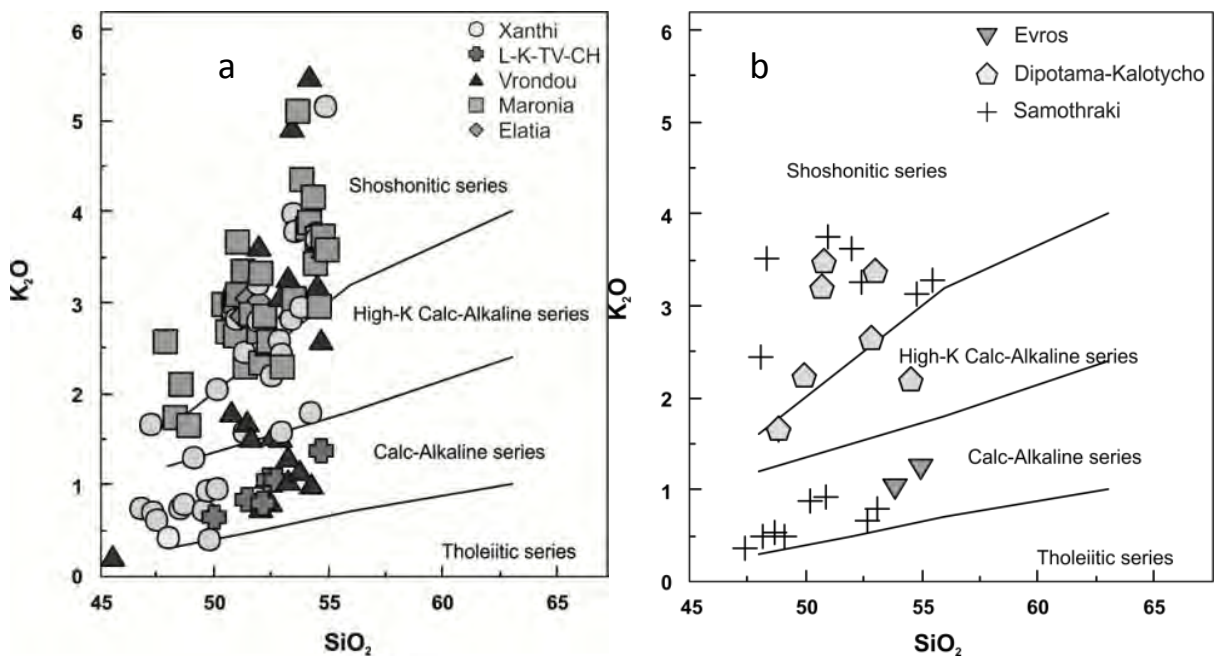

Figure $2-\mathrm{SiO}_{2}$ vs $\mathrm{K}_{2} \mathrm{O}$ of the plutonic rocks (a) and volcanic rocks (b) after Peccerillo \& Taylor 1976.
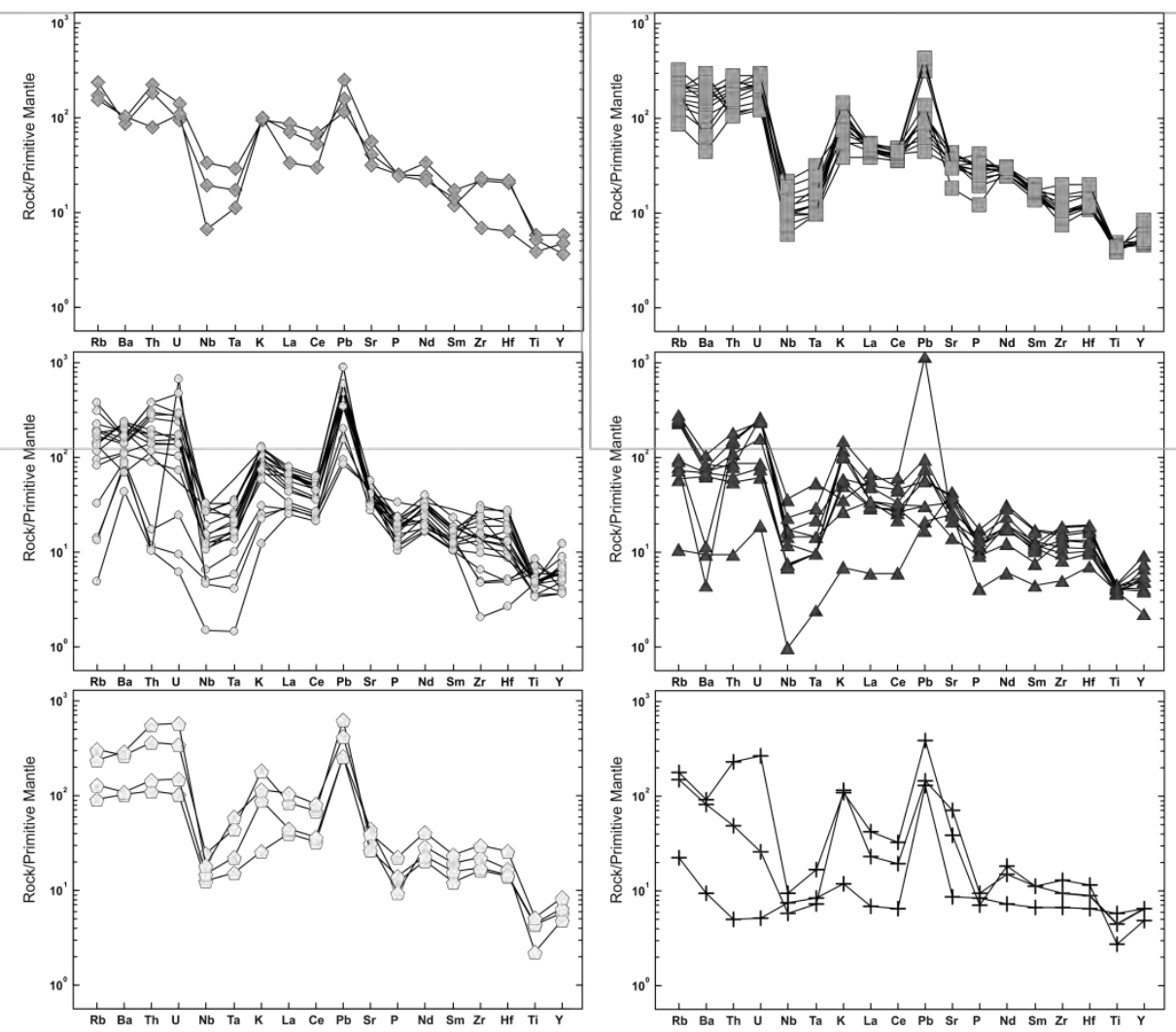

Figure 3 - Primitive mantle normalized multi-element diagrams. Normalization values after Sun \& McDonough (1989). Symbols as in Figure 2.

XLVII, No $1-421$ 

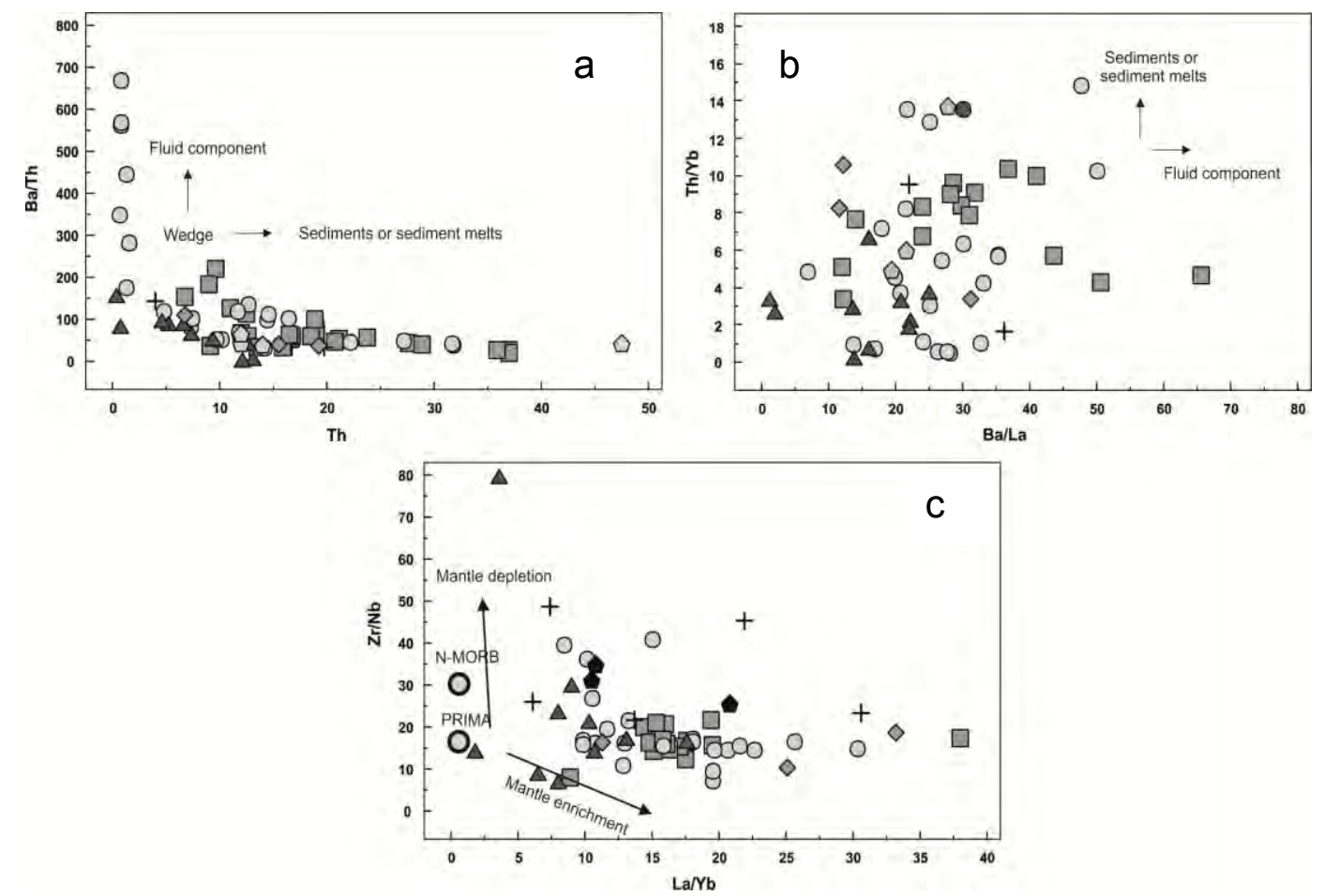

Figure 4 - a) Ba/Th vs Th as indicator of fluid or sediment component (Elliot et al., 1997) b) $\mathrm{Th} / \mathrm{Yb}$ vs Ba/La as indicator of fluid or sediment component (Hawkesworth et al., 1997) c) $\mathrm{Zr} / \mathrm{Nb}$ vs La/Yb for source enrichment (Münker, 2000). Symbols as in Figure 2.

and extensional collapse. Convective removal is another subduction model which predicts convective thinning of the unstable thickened lithospheric mantle and may result in removal of the whole mantle lithosphere and its replacement by hot asthenosphere. This will cause fast uplift of the overlying crust. According to Marchev et al. (2004) the above models have many shortcomings and are not able to describe the Rhodope magmatism. The same authors propose a form of convectional thinning of the lithosphere and of mantle diapirism due to asthenospheric origin of basalts they analyzed. So far, due to the lack of asthenospheric derived rocks in the Greek part of the Rhodope Massif, the above theory seems to interpret the Tertiary Rhodopian magmatism better than the previous. A more satisfactory explanation needs to be proposed and is under study for the Greek part of Rhodope.

Regarding the available geochemical data, an enriched and depleted mantle source existed simultaneously and generated the magmatic rocks of Rhodope. A 'leopard skin' mantle wedge during the Tertiary, which was able to produce a wide range of mafic magmas has been proposed from Perugini et al. (2004) to explain the heterogeneous mantle under RM. The same authors proposed the influence of the uprising asthenospheric mantle since the high $\mathrm{K}_{2} \mathrm{O}$ and the high LILE abundances are not in agreement with the relatively low $\mathrm{Sr}$ and high $\mathrm{Nd}$ isotopic values. Nevertheless, satisfactory data to support the above proposal are missing.

The enrichment of the mantle wedge above the subducted oceanic crust was caused from sediments or sediment melts derived from the subducted ocean. The MORB-like patterns of some dykes from Samothraki reflects strong mantle depletion. The no-negative $\mathrm{Nb}$-Ta anomaly of one sample from Samothraki may imply asthenospheric contribution. The present study is in progress and more geochemical and isotopic data are to be presented in order to give satisfactory explanations on the nature of the Rhodopian magmatism and the processes that took place. 

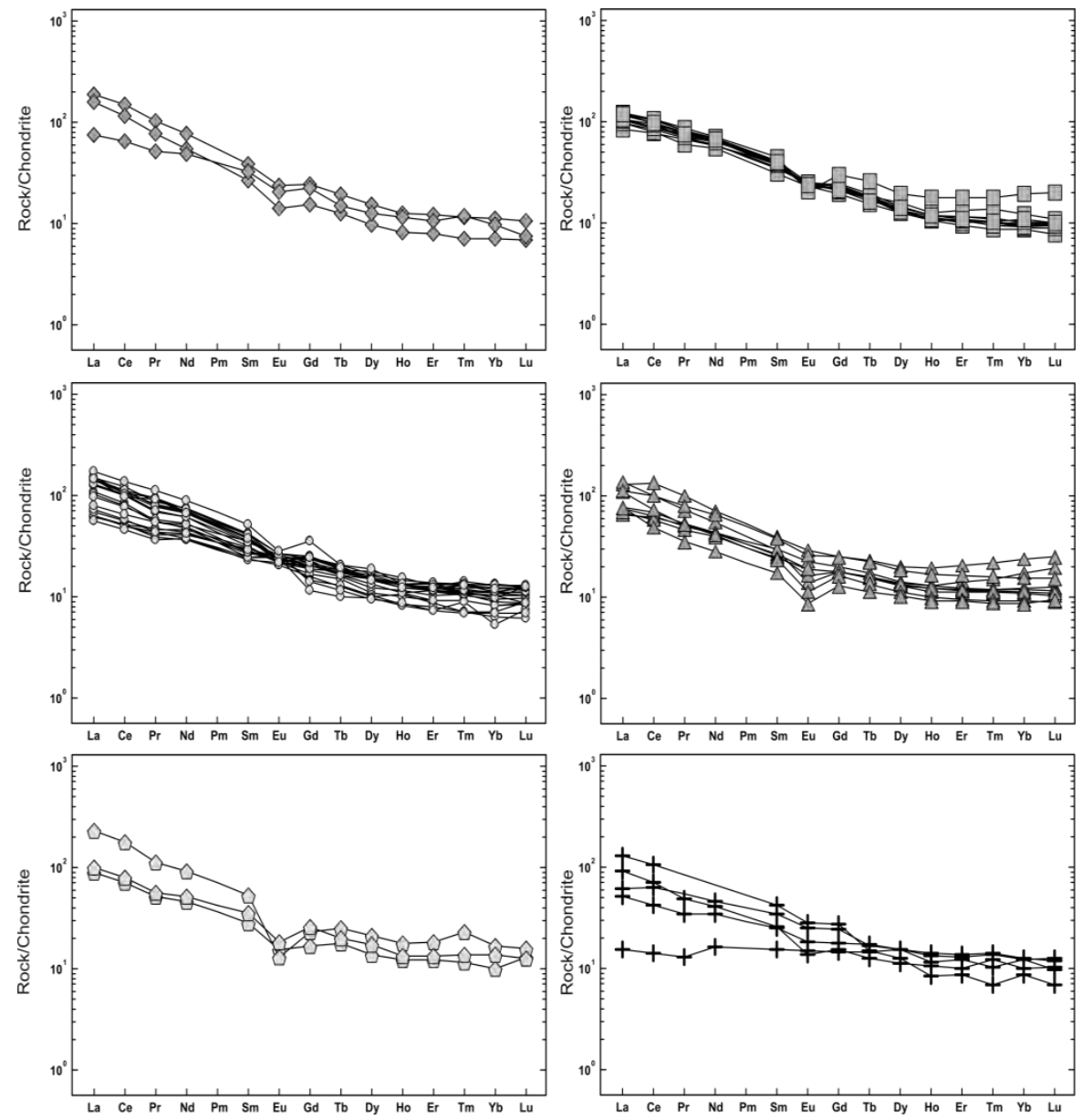

Figure 5 - Chondrite normalized multi-element diagrams. Normalization values after Boynton (1984). Symbols as in Figure 2.

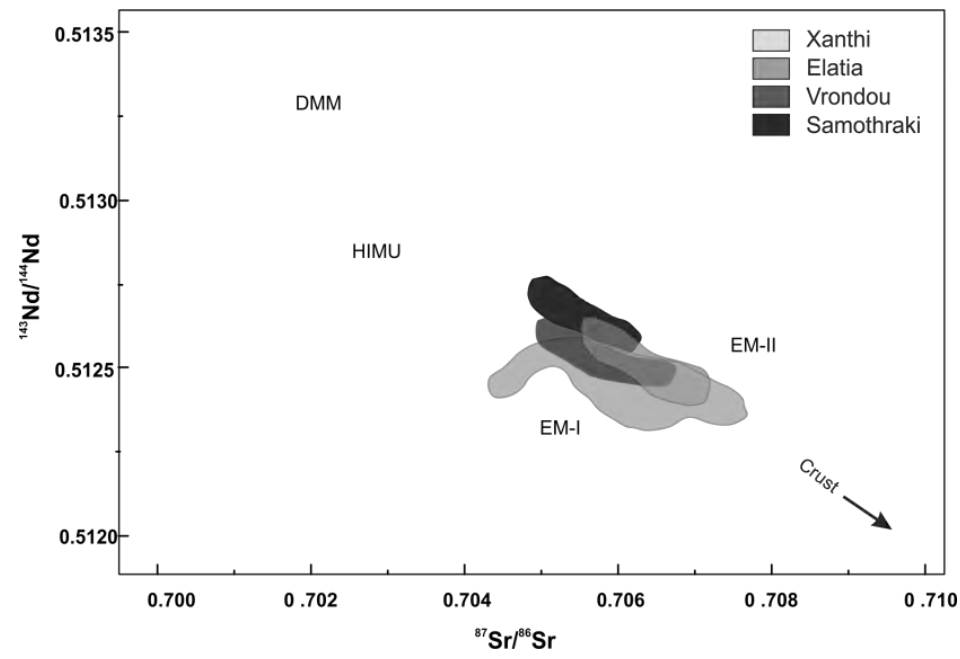

Figure $6-{ }^{143} \mathrm{Nd} /{ }^{144} \mathrm{Nd}$ vs ${ }^{87} \mathrm{Sr} /{ }^{86} \mathrm{Sr}$ with some mantle reservoirs illustrated. Symbols as in Figure 2.

$\underline{\text { XLVII, No } 1-423}$ 


\section{Acknowledgments}

This research has been co-financed by the European Union (European Social Fund - ESF) and Greek national funds through the Operational Program "Education and Lifelong Learning" of the National Strategic Reference Framework (NSRF) - Research Funding Program: Heracleitus II. Investing in knowledge society through the European Social Fund.

Authors would deeply like to thank Prof. Georgia Pe-Piper for the XRF analyses of some rocks. Critical reviews by Georgia Pe-Piper and two anonymous reviewers helped us improve the article.

\section{References}

Barr S.R., Temperley S. and Tarney J. 1999. Lateral growth of the continental crust through deep level subduction-accretion: a re-evaluation of central Greek Rhodope, Lithos, 46(1), 69-94.

Bonev N., Burg J. P. and Ivanov Z. 2006. Mesozoic-Tertiary structural evolution of an extensional gneiss dome-the Kesebir-Kardamos dome, eastern Rhodope (Bulgaria-Greece), International Journal of Earth Sciences, 95(2), 318-340.

Bonev N. and Beccaletto L. 2007. From syn-to post-orogenic Tertiary extension in the north Aegean region: constraints on the kinematics in the eastern Rhodope-Thrace, BulgariaGreece and the Biga Peninsula, NW Turkey, Geological Society, London, Special Publications, 291(1), 113-142.

Bonev N. and Stampfli G. 2008. Petrology, geochemistry and geodynamic implications of Jurassic island arc magmatism as revealed by mafic volcanic rocks in the Mesozoic low-grade sequence, eastern Rhodope, Bulgaria, Lithos, 100(1), 210-233.

Burg, J. P., Ricou, L. E., Ivano, Z., Godfriaux, I., Dimov, D., \& Klain, L., 1996. Syn-metamorphic nappe complex in the Rhodope Massif. Structure and kinematics, Terra Nova, 8(1), 6-15.

Christofides G. 1977. Contribution to the study of plutonic rocks in the area of Xanthi, Ph.D. thesis, Univeristy of Thessaloniki, $249 \mathrm{pp}$.

Christofides G., Pecskay G., Eleftheriadis Z., Soldatos G. and Koroneos T. 2002. Tertiary Evros volcanic rocks, Thrace, Northeastern Greece: Petrology, K/Ar geochronology and volcanism evolution, Extended Abstract $C B G A$, Bratislava.

Christofides G., Soldatos T., Eleftheriadis G. and Koroneos A. 1998. Chemical and isotopic evidence for source contamination and crustal assimilation in the Hellenic Rhodope plutonic rocks, Acta Vulcanologica, 10, 305-318.

Christofides G., Koroneos A., Pipera K., Poli G. and Soldatos T. 2011. The Oligocene Xanthi Plutonic Complex (N. Greece): Petrogenetic implications inferred from major and trace element and $\mathrm{Sr}, \mathrm{Nd}$ and $\mathrm{Pb}$ isotope geochemistry, Abstract, VII Hutton Symposium on Granites and Related Rocks, Avila, Spain.

Del Moro A., Innocenti F., Kyriakopoulos C., Manetti P. and Papadopoulos, P. 1988. Tertiary granitoids from Thrace (Northern Greece): Sr isotopic and petrochemical data, Neues Jahrbuch für Mineralogie Abhandlungen, 159, 113-135.

Dinter D.A., Macfarlane A., Hames W., Isachsen C., Bowering S. and Royden L. 1995.V-Pb and ${ }^{40} \mathrm{Ar}{ }^{39} \mathrm{Ar}$ geochronology of the Symvolon granodiorite: Implications for the thermal and structural evolution of the Rhodope metamorphic core complex, northeastern Greece, Tectonics, 14(4), 886-908.

Dinter D. A., and Royden L. 1993. Late Cenozoic extension in northeastern Greece: Strymon Valley detachment system and Rhodope metamorphic core complex, Geology, 21(1), 4548.

Doryphoros K. 1990. The Maronia pluton and its metamorphic effects on the surrounding rocks of the Makri series, Ph.D. Thesis, National Technical University of Athens, $166 \mathrm{pp}$.

Eleftheriadis G. 1995. Petrogenesis of the Oligocene volcanics from the Central Rhodope massif (N. Greece), European Journal of Mineralogy, 7(5), 1169-1182. 
Ellam R.M and Hawkesworth, C. J. 1988. Elemental and isotopic variations in subduction related basalts: evidence for a three component model, Contributions to Mineralogy and Petrology, 98(1), 72-80.

Elliott T., Plank T., Zindler A., White W., and Bourdon B. 1997. Element transport from slab to volcanic front at the Mariana arc, Journal of Geophysical Research, 102(B7), 14991-15.

Georgiev N., Pleuger J., Froitzheim N., Sarov S., Jahn-Awe S. and Nagel T. J. 2010. Separate Eocene-Early Oligocene and Miocene stages of extension and core complex formation in the Western Rhodopes, Mesta Basin, and Pirin Mountains (Bulgaria), Tectonophysics, 487(1), 59-84.

Hawkesworth C., Turner S., Peate D., McDermott F. and van Calsteren, P. 1997. Elemental U and Th variations in island arc rocks: implications for U-series isotopes, Chemical Geology, 139(1), 207-221.

Jones C.E. Tarney J., Baker J. H., and Gerouki F. 1992. Tertiary granitoids of Rhodope, northern Greece: Magmatism related to extensional collapse of the Hellenic Orogen?, Tectonophysics, 210(3), 295-314.

Kauffmann G., Kockel F., Mollat H. 1976. Notes on the stratigraphic and paleogeographic position of the Svoula Formation in the Innermost Zone of the Hellenides (Northern Greece), Bulletin de la Societe géologique de France (7), 28, 2, 225-230.

Kilias A. and Mountrakis D. 1990. Kinematics of the crystalline sequences in the western Rhodope massif, Geologica Rhodopica, 2, 100-116.

Kilias A. and Mountrakis D. 1998. Tertiary extension of the Rhodope massif associated with granite emplacement (Northern Greece), Acta Vulcanologica, 10, 331-338.

Kilias A., Falalakis G., Sfeikos A., Papadimitriou E., Vamvaka A., and Gkarlaouni Ch. 2011. Architecture of Kinematics and Deformation History of the Tertiary Supradetachment Thrace Basin: Rhodope Province (NE Greece), New Frontiers in Tectonic Research - At the Midst of Plate Convergence, Uri Schattner (Ed.)

Kockel F., Mollat H. and Walther H.W. 1977. Erläuterungen zur geologischen Karte der Chalkidhiki und angrenzender Gebiete 1:100,000 (Nord-Griechenland), Bundesanstalt für Geowissenschaften und Rohstoffe, Hannover, 119 pp.

KoukouveIas L., Pe-Piper G. 1991. The Oligocene Xanthi pluton, northern Greece: a granodiorite emplaced during regional extension, J Geol Soc Lond, 148, 749-758.

Krohe A. and Mposkos E. 2002. Multiple generations of extensional detachments in the Rhodope Mountains (northern Greece): evidence of episodic exhumation of high-pressure rocks, Special Publication-Geological Society of London, 204, 151-178.

Liati A. 1986. Regional metamorphism and overprinting contact metamosprhism of the Rhodope zone near Xanthi (N.Greece), Ph.D. Thesis, Techn. Univ. Braunschweig, 186 pp.

Liati A., Gebauer D. and Fanning, C.M. 2011. Geochronology of the Alpine UHP Rhodope zone: a review of isotopic ages and constraints on the geodynamic evolution. In: L.F. Dobrzhinetskaya, S.W. Faryad, S. Wallis, S. Cuthbert (Eds.), Ultrahigh-Pressure Metamorphism: 25 Years After The Discovery of Coesite and Diamond, Elsevier, London (2011), 295-316.

Lips A.L., White S. H. and Wijbrans J. R. 2000. Middle-late Alpine thermotectonic evolution of the southern Rhodope Massif, Greece, Geodinamica Acta, 13(5), 281-292.

Marchev P., Raicheva R., Downes H., Vaselli O., Chiaradia M., and Moritz R. 2004. Compositional diversity of Eocene-Oligocene basaltic magmatism in the Eastern Rhodopes, SE Bulgaria: implications for genesis and tectonic setting, Tectonophysics, 393(1), 301-328.

Marchev P., Kaiser-Rohrmeier, M., Heinrich C., Ovtcharova M., von Quadt A. and Raicheva R. 2005. Hydrothermal ore deposits related to post-orogenic extensional magmatism and core complex formation: The Rhodope Massif of Bulgaria and Greece, Ore Geology Reviews, 27(1), 53-89. 
Mavroudchiev B., Nedyalkov R., Eleftheriadis G., Soldatos T. and Christofides G. 1993. Tertiary plutonic rocks from east Rhodope in Bulgaria and Greece, Bull. Geol Soc. Greece, XXVIII/2, 643-660.

Meinhold G., Kostopoulos D., Frei D., Himmerkus F. and Reischmann T. 2010. U-Pb LA-SFICP-MS zircon geochronology of the Serbo-Macedonian Massif, Greece: palaeotectonic constraints for Gondwana-derived terranes in the Eastern Mediterranean, International Journal of Earth Sciences, 99(4), 813-832.

Mposkos E. 1989. High-pressure metamorphism in gneisses and pelitic schists in the east Rhodope zone (N. Greece), Mineralogy and Petrology, 41(1), 25-39.

Münker C. 2000. The isotope and trace element budget of the Cambrian Devil River arc system, New Zealand: identification of four source components, Journal of Petrology, 41(6), 759788.

Papadopoulou L., Christofides G., Koroneos A., Bröcker M., Soldatos T. and Eleftheriadis G. 2004. Evolution and origin of the Maronia pluton, Thrace, Greece, Bulletin of the Geological Society of Greece, 36.

Papanikolaou D. and Panagopoulos A. 1981. On the structural style of southern Rhodope, Greece, Geologica Balcanica, 11(3), 13-22.

Perugini D., Poli G., Christofides G., Eleftheriadis G., Koroneos A. and Soldatos T. 2004. Mantlederived and crustal melts dichotomy in northern Greece: spatiotemporal and geodynamic implications, Geological Journal, 39(1), 63-80.

Pe-Piper G., Christofides G. and Eleftheriadis G. 1998. Lead and neodymium isotopic composition of Tertiary igneous rocks of northern Greece and their regional significance, Acta Vulcanologica, 10, 255-264.

Ricou L.-E., Burg J-P., Godfriaux I. and Ivanov Z. 1998. Rhodope and Vardar: the metamorphic and the olistostromic paired belts related to the cretaceous subduction under Europe, Geodin Acta 11, 285-309.

Sokoutis D., Brun J. P., Van Den Driessche J. and Pavlides, S. 1993. A major Oligo-Miocene detachment in southern Rhodope controlling north Aegean extension, Journal of the Geological Society, 150(2), 243-246.

Soldatos T., Koroneos A., Kamenov B. K., Peytcheva I., von Quadt A., Christofides G. and Sang H. 2008. New U-Pb and Ar-Ar mineral ages for the Barutin-Buynovo-Elatia-SkalotiParanesti batholith (Bulgaria and Greece): Refinement of its debatable age, Geochem Mineral Petrol, 46, 85-102.

Soldatos T., Poli G., Christofides G., Eleftheriadis G., Koroneos A. and Tommasini S. 1998. Petrology and evolution of transitional alkaline-subalkaline granitoids from Vrondou (NE Greece): evidence for fractional crystallization and magma mixing, Acta Vulcanologica, 10, 319-330.

Turpaud P. 2006. Characterization of igneous terranes by zircon dating: implications for the UHP relicts occurrences and suture identification in the Central Rhodope, Northern Greece, Northern Greece, PhD thesis, Johannes Gutenberg University, Mainz, 107 pp.

Turpaud P. and Reischmann, T. 2010. Characterisation of igneous terranes by zircon dating: implications for UHP occurrences and suture identification in the Central Rhodope, northern Greece, International Journal of Earth Sciences, 99(3), 567-591.

Vlahou M., Christofides G., Eleftheriadis G., Pinarelli L. and Koroneos A. 2006. Tertiary volcanic rocks from Samothraki island (north Aegean, Greece): $\mathrm{Sr}$ and $\mathrm{Nd}$ isotope constraints on their evolution. Postcollisional Tectonics and Magmatism in the Mediterranean Region and Asia, 409, 283.

Yanev Y., Innocenti F., Manetti P. and Serri, G. 1998. Upper Eocene-Oligocene collision-related volcanism in Eastern Rhodopes (Bulgaria)-Western Thrace (Greece): petrogenetic affinity and geodynamic significance, Acta Vulcanologica, 10, 279-292. 